\title{
BUDAYA MENGINTEGRASIKAN KARAKTER RELIGIUS DALAM KEGIATAN SEKOLAH DASAR
}

\author{
Sabar Narimo (1) \\ Universitas Muhammadiyah Surakarta \\ sn124@ums.ac.id \\ Muhtar Sanusi (2) \\ Universitas Muhammadiyah Surakarta \\ sanusi67@gmail.com
}

DOI: 10.23917/varidika.v32i2.12866

\begin{abstract}
Submission
Track:

ABSTRAK

Received:

10 October 2020

Tujuan penelitian pada artikel ini ada tiga. 1) Mendeskripsikan

Final Revision: budaya mengintegrasikan karakter religius dalam kegitan kurikuler. 2) Mendeskripsikan budaya mengintegrasikan karakter religius dalam kegiatan ekstrakurikuler sekolah. 3) Mendeskripsikan budaya

10 November 2020 mengintegrasikan karakter religius dalam kegiatan kokurikuler. Jenis penelitian kualitatif etnografi. Tempat penelitian di Sekolah Dasar

Available online: Muhammadiyah 16 Karangasem Surakarta. Subjek penelitian, kepala sekolah, guru, karyawan, dan siswa semester genap 2019/2020.

8 December 2020 Teknik pengumpulan data dengan wawancara, observasi, dan dokumentasi. Teknik analisis data denga metode induktif. Hasil Corresponding

Author:

Sabar Narimo (1)

sn124@ums.ac.id

Muhtar Sanusi (2)

penelitian, 1) Kegiatan kurikuler dalam menanamkan religius, yaitu membiasakan penghayatan terhadap suatu ajaran, ideologi, doktrin, atau nilai sehingga merupakan keyakinan dan kesadaran akan realitas atau nilai yang diwujudkan dalam sikap dan perilaku, sehingga menjadi siswa yang berwatak dan berbudi pekerti sesuai ajaran agama yang dianutnya. Kegiatan yang terkait dengan pembiasan karakter religius, yaitu salam, doa sebelum dan sesudah sanusi67@gmail.com belajar. 2) Budaya mengintegrasikan karakter religius dalam kegitan ekstrakurikuler terkait dengan pembiasaan salam, Doa sebelum dan sesudah belajar, Sholat Dhuha, peringatan hari besar islam, Membaca Al-Ma'tsurot, memakai peci, Kegiatan tadarus, penelolaan infak, dan dahwah romadhan. 3) Budaya mengintegrasikan karakter religius dalam kegitan kokurikuler, terkait dengan pembiasaan Baca Tulis Al-qur'an, kultum ba'da dhuhur, Peringatan Hari Besar Islam, zakat dan qurban.

Kata Kunci: budaya, karakter, religius, kegiatan sekolah.
\end{abstract}




\section{PENDAHULUAN}

Pembentukan karakter melalui pendidikan karakter pada dasarnya berangkat dari berbagai macam permasalahan yang menyangkut generasi muda di era globalisasi sekarang ini. Kondisi putra-putri bangsa semakin memprihatinkan dilihat dari cara pergaulan mereka, gaya hidup, penurunan semangat belajar, masalah narkoba, bahkan kriminalitas yang menjerat anakanak di bawah umur seakan sudah menjadi hal yang biasa belakangan ini.

Melihat dari situasi kebanyakan generasi muda saat ini dan dengan adanya wacana pembentukan karakter pada pribadi bangsa, maka muncullah berbagai variasi dari pendidikan karakter. Dirumuskannya pendidikan karakter adalah guna membentuk bangsa yang kuat dan berkarakter, bermartabat, serta disegani di dunia internasional. Untuk mendapatkan bangsa dan negara semacam itu perlu penerapan pendidikan karakter yang benar. Di Indonesia sendiri pendidikan karakter telah cukup lama didengungkan dalam dunia pendidikan.

Menurut Hamid (2017: 29) Pendidikan karakter yang kemudian menjadi character education menjadi tema populer saat ini, terutama setelah dicanangkan oleh Kementerian Pendidikan pada 2 Mei 2010. Menteri pendidikan nasional mendeklarasikan dimulainya pendidikan karakter bangsa. Kementerian Pendidikan Nasional (Gunawan, 2014: 33) mengemukakan ada 18 nilai-nilai karakter yang akan ditanamkan kepada generasi muda Indonesia. Karakter-karakter ini yaitu: religius, jujur, toleransi, disiplin, kerja keras, kreatif, mandiri, demokratis, rasa ingin tahu, semangat kebangsaan, cinta tanah air, menghargai prestasi, komunikatif/bersahabat, cinta damai, gemar membaca, peduli lingkungan, peduli sosial, dan tanggung jawab.

Para pakar pendidikan pada umumnya sependapat tentang pentingnya upaya peningkatan pendidikan karakter pada jalur pendidikan formal. Namun demikian, ada perbedaan-perbedaan pendapat di antara mereka tentang pendekatan dan model pendidikannya. Sebagian pakar cenderung menggunakan pendekatan pendidikan moral dari negara barat seperti perkembangan moral kognitif, pendekatan analisis nilai, dan pendekatan klarifikasi nilai. Sebagian yang lain cenderung menggunakan pendekatan tradisional, yakni melalui penanaman nilai-nilai sosial tertentu dalam diri siswa (Gunawan, 2014: 24).

Pembentukan dan pendidikan karakter siswa secara intensif merupakan suatu keharusan dan tidak bisa ditunda. Hal ini dapat dilakukan apabila semakin banyak waktu siswa untuk berada di sekolah. Sehingga hal tersebut memungkinkan guru untuk memberikan arahan, pembiasaan, dan bimbingan kepada siswa. Misal bagaimana harus bersikap terhadap yang lebih 
tua, lebih muda, dan teman sebayanya. Pentingnya pendidikan karakter yang dilaksanakan oleh sekolah sejalan dengan pendapat dari Pala (2012: 23) yang menyatakan "To be effective, character education mustinclude the entire school community and must be infused throughout the entireschool curriculum and culture", pendapatnya ini dapat diartikan bahwa agar dapat berjalan efektif, pendidikan karakter harus dimasukkan ke dalam lingkungan sekolah dan harus ditanamkan melalui kurikulum dan budaya sekolah.

Mengingat pentingnya pendidikan karakter bagi anak bangsa dan didasarkan dari 18 nilai karakter oleh Kementerian Pendidikan yang telah disebutkan sebelumnya, maka penelitian ini mengangkat salah satu karakter yang paling pokok, mendasar, dan efektif untuk mengontrol perilaku dan membentuk karakter siswa yang baik, yakni karakter religius. Pendidikan karakter religius ini telah diimplementasikan oleh banyak sekolah baik dalam bentuk program full day school, boarding school, maupun sekolah-sekolah yang berbasis agama.

Sekolah merupakan salah satu tempat yang strategis dalam pembentukan karakter selain di keluarga dan masyarakat (Hamid, 2017: 3). Hal itulah yang mendasari perlu adanya program pendidikan karakter di sebuah sekolah, baik dalam kegiatan intrakurikuler, kokurikuler, dan ekstrakurikuler sekolah. Oleh sebab itu, perlu penanaman pendidikan karakter untuk tiap sekolah dengan berbagai kegiatan yang bisa menunjang penanaman karakter yang baik ini.

Salah satu kegiatan yang dapat dilakukan sebagai upaya untuk menguatkan dan menanamkan nilai-nilai karakter adalah dengan kegiatan pembiasaan yang dilakukan di sekolah. Karena memang hal yang rutin dilakukan setiap hari akan tertanam dengan baik dalam diri peserta didik maupun warga sekolah yang lain. Maka dari itu kegiatan pembiasaan ini menjadi kegiatan yang sangat penting bagi terlaksananya pendidikan karakter yang ada di sekolah. Seperti yang dijabarkan oleh Wibowo (2013: 21-22) bahwa kebiasaan kehidupan di sekolah dan budaya sekolah yang baik dapat menumbuhkan nilai-nilai pendidikan karakter. Oleh karena budaya sekolah (school culture) merupakan salah satu kunci keberhasilan pendidikan karakter.

Pembentukan karakter dapat diwujudkan melalui sistem pendidikan. Diharapkan di masa depan, dapat mencetak lulusan yang dapat membangun bangsa tanpa meninggalkan nilainilai karakter yang mulia. Menurut Asmani (2011), jenis karakter yang diterapkan dalam proses pendidikan ada empat, yaitu: 1) Pendidikan karakter berbasis nilai religius; 2) Pendidikan karakter berbasis nilai budaya; 3) Pendidikan karakter berbasis lingkungan; dan 4) Pendidikan 
karakter berbasis potensi diri. Penanaman nilai-nilai karakter yang pertama dapat dimulai melalui pendidikan karakter berbasis nilai religius.

Munculnya lembaga pendidikan dengan konsep pendidikan berbasis kurikulum nasional dan pendidikan berbasis religius secara terpadu memiliki karakteristik dan bagian yang tidak terpisahkan dalam pembaharuan pendidikan Islam di Indonesia, terutama pembaharuan dalam segi bentuk dan model lembaga pendidikan agama Islam. Oleh karena itu, kurikulum yang diterapkan sekolah harus bisa mengintegrasikan visi, misi, dan tujuan sekolah pada setiap mata pelajaran dan kegiatan sekolah. Dengan demikian, masing-masing program kegiatan tersebut dapat memperkuat kurikulum.

Sahlan (2010: 77) menjelaskan bahwa dalam penguatan karakter religius dapat dilakukan melalui: peraturan kepala sekolah, implementasi kegiatan belajar mengajar, kegiatan ektrakurikuler, budaya dan perilaku yang dilaksanakan semua warga sekolah secara terusmenerus. Sehingga penguatan karakter berbasis religius dapat tercapai sesuai yang diharapkan oleh sekolah. Beberapa upaya yang dapat dilakukan untuk mewujudkan kegiatan tersebut adalah mencontohkan keteladanaan, menciptakan lingkungan yang kondusif, dan ikut berperan aktif.

Program-program kegiatan religius di sekolah harus dilaksanakan secara kontinyu dan berkesinambungan. Sebagai upaya penguatan pendidikan karakter peserta didik dimasa sekarang ini. Dalam hal ini, budaya dan kultur masing-masing sekolah sangat mempengaruhi sistem manajemen sekolah yang akan membentuk visi, misi, dan tujuan sekolah itu sendiri. Sehingga lulusan yang akan dihasilkan dari masing-masing sekolah juga akan membawa pengaruh terhadap kehidupan masyarakat. Harapan pemerintah, semua Lembaga Pendidikan bisa mewujudkan tujuan pendidikan secara maksimal.

Untuk membina hal tersebut tentunya harus ditunjang oleh faktor-faktor pendukung pendidikan seperti lingkungan, kurikulum, media, materi dan lain sebagainya, termasuk juga beberapa kegiatan penunjang yang bisa digunakan pada sekolah-sekolah seperti kurikuler, kokurikuler, dan ekstrakurikuler. Kegiatan kokurikuler dan ekstrakurikuler saling mempunyai keterkaitan dengan kegiatan kurikuler, satu dengan yang lainnya harus saling mendukung guna mencapai tujuan. Kegiatan kokurikuler merupakan suatu kegiatan yang langsung mendukung 
kegiatan kurikuler. Kegiatan ekstrakurikuler merupakan kegiatan yang mendukung kegiatan kurikuler secara tidak langsung.

Adanya ketiga kegiatan tersebut di sekolah, dimaksudkan agar siswa lebih mendalami dan menghayati apa yang dipelajari dalam kegiatan intrakurikuler. Kegiatan kokurikuler biasannya dituangkan dalam bentuk pekerjaan rumah atau penugasan. Dalam memberikan tugas kepada siswa, materi yang diberikan biasannya disesuaikan dengan bidang studi yang bersangkutan, karena penugasan tersebut dimaksudkan untuk memperdalam pengetahuan tentang materi yang diberikan di kelas.

Berdasarkan uraian di atas, tujuan penelitian pada artikel ini ada tiga. 1) Mendeskripsikan budaya mengintegrasikan karakter religius dalam kegitan kurikuler. 2) Mendeskripsikan budaya mengintegrasikan karakter religius dalam kegiatan ekstrakurikuler sekolah. 3) Mendeskripsikan budaya mengintegrasikan karakter religius dalam kegiatan kokurikuler.

\section{METODE PENELITIAN}

Berdasarkan pendekatannya ini merupakan penelitian kualitatif dengan desain etnografi (Sutama, 2019). Data penelitian dari berbagai sumber tentang peristiwa atau kejadian yang berlangsung secara alami dilakukan tanpa terjadinya pengendalian peneliti atau yang biasanya disebut manipulasi data. Tempat penelitian di SD Muhammadiyah 16 Karangasem Surakarta. Subjek penelitian, kepala sekolah, guru, karyawan, dan siswa semester genap 2019/2020.

Pengumpulan data dilakukan dengan teknik observasi, wawancara, dan dokumentasi. Observasi dilakukan dengan cara memperhatikan dan mengamati seluruh kondisi dan kegiatan yang ada dalam sekolah yang berkaitan erat dengan terciptanya penanaman atau pembentukan karakter pada siswa (Moleong, 2010: 174). Wawancara dilakukan kepada informan baik, guru, kepala sekolah, staf karyawan yang digunakan untuk mengetahui bagaimana penananman pendidikan karakter pada siswa. Wawancara dilaksanakan untuk menggali informasi yang belum diperoleh dari hasil observasi (Moleong, 2010:186). Proses pengamatan dicatat dalam catatan lapangan dan didokumentasikan dalam bentuk foto sehingga dapat digunakan untuk membantu proses refleksi. Dokumentasi yang digunakan dalam penelitian ini adalah dokumendokumen atau catatan yang mendukung dalam proses pembentukan karakter siswa.

Data yang terkumpul dinalisis dengan menggunakan teknik analisis induktif seperti yang dikemukakan oleh Miles dan Huberman (2002). Analisis dilakukan dengan empat 
tahapan, yaitu tahapan pengumpulan data, reduksi data, penyajian data, dan verivikas serta penarikan kesimpulan.

\section{HASIL PENELITIAN DAN PEMBAHASAN}

\section{Budaya mengintegrasikan karakter religius dalam kegitan kurikuler}

Pendidikan karakter yang di integrasikan dalam kegiatan kurikuler, tidak dapat mencapai hasil maksimal tanpa perencanaan yang baik. Kualitas perencanaan pendidikan karakter yang diaplikasikan di setiap sekolah sangat menentukan kesuksesan penerapan pendidikan karakter, dan untuk mencapai keberhasilan segala sesuatunya harus direncanakan terlebih dahulu. Untuk mencapai sukses dalam penerapan pendidikan karakter, sekolah perlu mempersiapkan terlebih apa saja yang akan direncanakan, perencanaan perlu disesuaikan dengan visi dan misi sekolah. Salah satu pendekatan untuk mendukung tercapainya tujuan pendidikan karakter adalah melalui model pembiasaan. Dengan demikian, perencanaan dalam pendidikan karakter adalah kegiatan persiapan yang perlu disusun terlebih dahulu agar proses pelaksanaan pendidikan karakter melalui pembiasaan dapat berjalan lancar sesuai tujuan. Selain itu, perencanaan yang matang akan semakin mempermudah guru dalam melaksanakan program pendidikan karakter.

Budaya kegiatan kurikuler (pembelajaran pada jam belajar) meliputi keseluruhan latar fisik, lingkungan, suasana, rasa, sifat dan iklim yang secara produktif mampu memberikan dorongan kepada siswa untuk melakukan aktivitas yang dibutuhkan siswa. Budaya kegiatan kurikuler mampu berubah berdasarkan faktor luar maupun dalam.

Budaya kegiatan kurikuler memiliki cakupan yang sangat luas, pada umumnya mencakup kegiatan ritual, harapan, hubungan sosio-kultural, aspek demografi, proses pengambilan keputusan, kebijakan maupun interaksi sosial antar komponen di sekolah. Budaya kegiatan kurikuler adalah suasana kehidupan sekolah di mana peserta didik berinteraksi dengan sesamanya, guru dengan guru, konselor dengan peserta didik, antar tenaga kependidikan, antar tenaga kependidikan dengan pendidik dan peserta didik, dan antar anggota kelompok masyarakat dengan warga sekolah. Interaksi internal kelompok dan antar kelompok terikat oleh berbagai aturan, norma, moral serta etika bersama yang berlaku di suatu sekolah. Kepemimpinan, keteladanan, keramahan, toleransi, kerja keras, disiplin, kepedulian sosial, kepedulian lingkungan, rasa kebangsaan, dan tanggung jawab merupakan nilai-nilai yang dikembangkan dalam budaya kegiatan kurikuler. 
Dalam kegiatan kurikuler individu belajar dan diterima menjadi bagian yang kemudian ke tahap pengukuhan diri ke dalam nilai-nilai dan norma-norma sosial dari perilaku suatu masyarakat. Kegiatan kurikuler dalam menanamkan religius, yaitu membiasakan penghayatan terhadap suatu ajaran, ideologi, doktrin, atau nilai sehingga merupakan keyakinan dan kesadaran akan realitas atau nilai yang diwujudkan di sikap dan perilaku.

Karakter religius dapat diartikan sebagai sikap dan perilaku yang taat dalam melaksanakan ajaran agama yang merupakan pokok pangkal terwujudnya kehidupan yang damai. Dengan demikian, proses penanaman karakter religius ataupun pendidikan akhlak sudah tentu harus dipandang sebagai usaha sadar dan terencana, bukan usaha yang sifatnya terjadi secara kebetulan. Jadi, budaya mengintegrasikan karakter religius merupakan upaya mendalami nilai-nilai agama agar tertanam dalam diri setiap siswa sehingga melahirkan seseorang yang berwatak dan berbudi pekerti sesuai ajaran agama yang dianutnya (Mushfi \& Fadilah, 2019: 8).

Ada beberapa penyebab ketidakmampuan seseorang untuk berperilaku baik, walaupun secara kognitif individu tersebut mengetahuinya (moral knowing) sebagaimana dikemukakan Muslich (2016), yaitu karena individu tersebut tidak terlatih untuk melakukan kebajikan atau moral action. Dalam pendidikan karakter, penekanan komponenkomponen karakter atau perilaku yang baik (components of good character) sangat penting untuk diterapkan. Hal ini sangat diperlukan agar siswa mampu memahami merasakan serta menerapkan sekaligus nilainilai kebajikan.

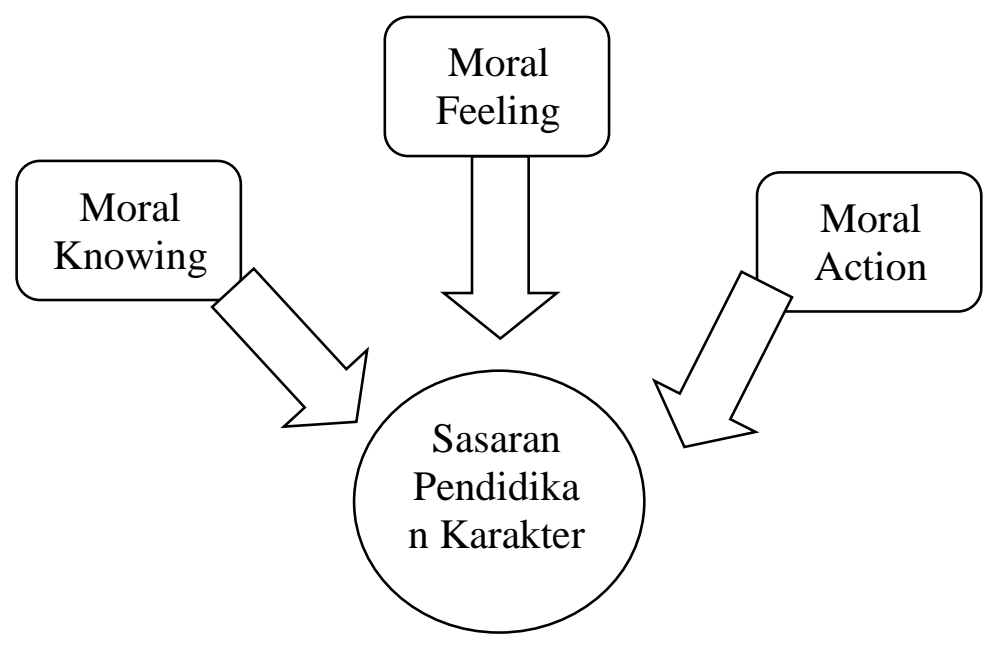

Gambar 1. Sasaran Pendidikan Moral

a. Moral knowing (pengetahuan tentang moral) merupakan hal yang penting untuk diajarkan. Moral knowing terdiri dari enam hal, yaitu: (1) moral awareness atau 
kesadaran moral, (2) knowing moral values atau mengetahui nilai-nilai moral, (3) perspective taking, (4) moral rasioning, (5) decision making, dan (6) self knowledge. Tahapan ini adalah langkah awal yang harus dilaksanakan dalam mengimplementasikan pendidikan karakter.

b. Moral feeling (perasaan moral) merupakan sumber energi dalam diri manusia untuk berperilaku sesuai dengan prinsip-prinsip moral. Moral feeling terdiri atas enam hal yang termasuk dalam aspek emosi yang harus dirasakan oleh seseorang demi menjadi manusia yang berkarakter yakni: (1) conscience (nurani), (2) confident (percaya diri), (3) empathy (merasakan kemalangan orang lain), (4) loving the truth (mencintai kebenaran), (5) self control (mampu mengontrol diri), dan (6) humility (kerendahan hati). Pada tahapan ini, sasaran guru adalah dimensi emosional siswa, hati, dan jiwa siswa. Tahap ini merupakan konsolidasi aspek emosi siswa untuk menjadi individu yang berkarakter sesuai dengan ajaran agama.

c. Moral action (tindakan moral) adalah sebuah cara untuk membuat pengetahuan moral bisa diwujudkan menjadi tindakan nyata. Untuk mengetahui seseorang dalam perbuatan baik (act morallity) maka harus dilihat tiga aspek lain dari karakter, yaitu competence, will, and habit. Pada tahap ini merupakan puncak keberhasilan dalam menginternalisasikan pembentukan karakter, yakni ketika siswa sudah mampu mempraktekkannya dalam tindakan nyata secara sadar.

Karakter seseorang akan semakin kuat bila ikut didorong adanya suatu ideology atau believe. Apabila semua talah tercapai, maka akan ada kesadaran awareness dalam diri seseorang untuk melakukan suatu perbuatan yang baik tersebut tanpa adanya paksaan atau dorongan untuk melakukannya. Selain itu, adanya faktor internal dalam keluarga atau masyarakat dapat mempengaruhi karakter seseorang.

\section{Budaya mengintegrasikan karakter religius dalam kegitan ekstrakurikuler}

Karakter religius terdapat pada urutan pertama. Jika setelah seseorang memiliki sikap religius maka sikap-sikap baik lainnya akan mengikuti dan menjadikan pondasi dasar seseorang dalam menjalankan kehidupannya, supaya tidak terombang-ambing oleh perubahan zaman yang semakin berkembang. Jujur juga termasuk dalam karakter harus dimiliki peserta didik, karena dengan sikap jujur inilah awal mula akan mendapat kepercayaan dari orang lain. Adapun untuk memiliki sikap jujur ini haruslah dimulai dari sikap jujur kepada dirinya sendiri baru 
berkembang sikap jujur kepada orang lain. Budaya mengintegrasikan karakter religius dalam kegitan ekstrakurikuler terkait dengan pembiasaan diluar jam pelajaran menenamkan perilaku atau tatakrama yang tersistematis dalam pengamalan agama Islam sehingga terbentuk kepribadian dan sikap yang baik (akhlaqul karimah) serta disiplin dalam berbagai hal.

Tujuan ekstrakurikuler sebagaimana tercantum dalam Permendiknas No. 39 tahun 2008, yaitu:

a. Mengembangkan potensi siswa secara optimal dan terpadu yakni meliputi bakat, minat dan kreativitas.

b. Sekolah sebagai lingkungan pendidikan sehingga terhindar dari usaha dan pengaruh negatif yang bertentangan dengan tujuan pendidikan.

c. Mengaktualisasikan potensi siswa dalam pencapaian prestasi ungulan sesuai bakat dan minat.

d. Menyiapkan siswa agar siap menjadi warga masyarakat yang berakhlak mulia, demokratis, menghormati hak-hak asasi manusia dalam rangka mewujudkan masyarakat madani (civil society).

Budaya ini bertujuan mengembangkan budaya bangsa yang posistif dalam membangun siswa sebagai manusia seutuhnya. Adapun diproritaskan kegiatan yang mengandung nilai karakter religius, antara lain:

a. Budaya Salam, penanaman budaya mengucapkan salam ini ditanamkan sejak siswa masuk pertama di sekolah ini. Sehingga menjadi kebiasaan yang sangat tertata ketika siswa satu bertemu dengan siswa lainnya atau dengan guru baik di ruang kelas maupun di luar kelas untuk mengucap salam. Budaya salam di SD tempat penelitian dilakukan di dalam kelas maupun di luar kelas tentang aktivitas siswa yang didahului dengan ucapan salam dan menyapa dengan ucapan salam.

b. Doa sebelum dan sesudah belajar, membaca doa dilakukan secara bersama dibaca dengan keras dipimpin ketua atau siswa lain. Selain itu berdoa bersama dapat menumbuhkembangkan sikap kebersamaan dalam kelas pada setiap mengawali dan mengakhiri pelajaran. 
c. Sholat Dhuha, kegiatan ini diakukan oleh semua siswa, guru dan karyawan, kegitatan ini dilakukan di musholla,

d. Peringatan Hari Besar Islam (PHBI), peringatan hari besar agama sebagai upaya untuk meneladani dan mengenal kembali kejadian sejarah pada masa lalu berkaitan dengan peristiwa penting pada masa nabi dan rosul.

e. Membaca Al-Ma'tsurot (dzikir pagi), zikir ini dilaksanakan sebelum sholat dhuha yang biasa di baca nabi Muhammad SAW tiap pagi dengan tujuan agar terhindar dari gangguan setan, dicukupi segala kebutuhannya, disempurnakan nikmatnya, serta sebagai tanda syukur, serta terhindar dari segala bahaya.

f. Memakai peci. Saat siswa melakukan kegiatan, seperti sholat berjamaah, pidato, hafalan surat-surat pendek, wajib memakai peci sebagai kelengkapan.

g. Kegiatan tadarus, kegiatan ini dilaksanakan sebelum pembelajaran dimulai sete;ah berdoa memulai pelajaran, yakni membaca beberapa surat dalam Al Qur'an secara bersama di dalam kelas masing-masing. Program ini sangat didukung oleh orang tua siswa.

h. Pengelolaan Infaq Sekolah

Pengelolaan infaq merupakan kegiatan yang dilaksanakan pada setiap kelas dengan mengumpulkan uang seikhlasnya yang dilaksanakan setiap hari Jumat. Kegiatan infaq sekolah ini dikelola oleh bendahara kelas kemudian disetor ke bagian bendahara sekolah untuk dihimpun sebagai uang yang diberikan atau diperbantukan bagi yang membutuhkan terutama pada kaum dhuafak atau untuk membantu kegiatan amal usaha yang belum berjalan maksimal dan dipandang masih perlu bantuan. Pengelolaan dana infaq merupakan bentuk pendidikan karakter yang memberikan pembelajaran pada siswa untuk senantiasa pandai mengatur keuangan dan dari sisi sosial sebagai upaya melatih siswa untuk lebih peduli terhadap keterbatasan kehidupan sesama manusia. Anak diajak untuk berfikir terhadap sikap yang dilakukan ketika kita memperlakukan pada orang yang kurang mampu dan kita sebisanya kita dapat membantunya.

i. Kegiatan Dakwah Ramadhan

Kegiatan tahunan yang menjadi rutinitas adalah kegiatan dakwah ramadhan. Kegiatan ini telah berjalan sejak berdirinya sekolah ini, kegiatan ini meliputi : Pertama kajian tafsir, kegiatan kajian tafsir yaitu kajian yang dilaksanakan untuk mengkaji dan mendalami Al Qur'an yang disampaikan oleh ustadz dari luar dan ustadz yang ada di sekolah. Kajian diikuti oleh semua siswa di SD tempat penelitian yang dilaksanakan di penghujung bulan ramadhan. Kegiatan ini juga dikenal dengan istilah pesantren kilat di sekolah. Kegiatan dilaksanakan selama 3 hari berturut-turut dari pukul 08.00 sampai 
dengan pukul 12.000 WIB atau menginjak waktu sholat dhuhur. Kedua hafalan surat pendek, kegiatan kajian sehabis sholat dhuhur untuk menghafal surat pendek maupun kajian tentang hadist. Kegiatan ini diikuti oleh seluruh siswa kelas tinggi di SD tempat penelitian. Ustadz yang membimbing adalah diambil dari guru di sekolah secara bergantian dan bahkan juga memberikan tugas pada siswa utnk membantu dan memandu kegiatan secara bergantian selama bulan ramadhan dan selama hari efektif masuk di sekolah di bulan ramadhan.

Berdasarkan uraian di atas, budaya mengintegrasikan karakter riligius dalam kegiatan ekstrakurikuler, antara lain sholat dhuha, ucapan salam, doa sebelum dan sesudah belajar, pembacaan almatsurat/dikir pagi jamaah sholat dhuhur dan kultum, tadarus, dan kegiatan ramadhan. Kegiatan ini selain menanamkan karakter religius juga menanamkan karakter disiplin, toleransi, mandiri, komunikatif, peduli sosial dan tanggung jawab.

\section{Budaya mengintegrasikan karakter religius dalam kegitan kokurikuler}

Pengembangan karakter dalam kegiatan kokurikuler, yakni kegiatan belajar di luar kelas yang terkait langsung pada suatu materi dari suatu mata pelajaran. Kegiatan pembinaan kesiswaan yang selama ini diselenggarakan sekolah, merupakan salah satu wadah yang potensial untuk pendidikan karakter. Kegiatan pembinaan kesiswaan merupakan pendidikan di luar mata pelajaran, untuk membantu pengembangan siswa sesuai dengan kebutuhan, potensi, bakat, dan minat mereka melalui kegiatan khusus. Melalui kegiatan pembinaan kesiswaan, siswa dapat difasilitasi untuk mengembangkan karakter mereka.

Kegiatan kokurikuler yang berorientasikan pendidikan karakter seperti kegiatan praktik dan diskusi pengayaan mata pelajaran sains, agama, dan olah raga baik di dalam kelas maupun di luar kelas. Untuk menunjang pendidikan karakter dalam pembelajaran sains di SD tempat penelitian, guru mengembangkan kegiatan kokurikuler dalam pembelajaran sains yaitu dengan memberikan penugasan berupa wawancara dan pengamatan yang dikerjakan bersama dalam kelompok, hasil dilaporkan dalam bentuk tulisan dan dipresentasikan di kelas. Hal tersebut dapat menanamkan karakter kerjasama antar teman sebaya, menumbuhkan karakter kejujuran dalam melaporkan hasil pengamatan maupun wawancara sesuai dengan data yang didapatkan. Metode pembelajaran yang sering digunakan oleh guru SD tempat penelitian adalah Discovery learning. Temuan ini sejalan dengan pendapat Asmani (2013), bahwa dengan menggunakan model discovery learning dapat meningkatkan kerjasama dan rasa ingin tahu peserta didik. Kemendikbud (2016) juga menjelaskan bahwa guru harus pandai memilih agar metode 
pembelajaran yang digunakan secara tidak langsung menanamkan pembentukan karakter peserta didik.

Kokurikuler merupakan kegiatan di luar jam pelajaran biasa (termasuk waktu libur) yang dilakukan di sekolah ataupun di luar sekolah dengan tujuan untuk memperluas pengetahuan siswa mengenai hubungan antara berbagai jenis pengetahuan, menyalurkan bakat dan minat, serta melengkapi upaya pembinaan manusia seutuhnya.

Kegiatan kokurikuler dapat dilaksanakan di perpustakaan, dirumah atau di tempat lain dalam bentuk membaca buku, penelitian, mengarang atau pekerjaan rumah. Kegiatan ini sebenarnya sudah mendukung pelaksanaan pendidikan karakter. Namun demikian, tetap diperlukan perencanaan, pelaksanaan, dan evaluasi yang baik atau merevitalisasi kegiatankegiatan kokurikuler tersebut agar dapat melaksanakan pendidikan karakter kepada siswa.

Bentuk-bentuk kegiatan kokurikuler yang dilaksanakan di SD tempat penelitian yang berbasis religius antara lain BTA (Baca Tulis Al-qur'an), kultum ba'da dhuhur, PHBI (Peringatan Hari Besar Islam), zakat dan qurban. Kegiatan kokurikuler bertujuan menunjang pelaksanaan program kurikuler secara langsung agar siswa dapat lebih menghayati bahan atau materi yang telah dipelajarinya serta melatih siswa untuk melaksanakan tugas secara bertanggung jawab.

\section{PENUTUP}

Kegiatan kurikuler dalam menanamkan religius, yaitu membiasakan penghayatan terhadap suatu ajaran, ideologi, doktrin, atau nilai sehingga merupakan keyakinan dan kesadaran akan realitas atau nilai yang diwujudkan dalam sikap dan perilaku, sehingga menjadi siswa yang berwatak dan berbudi pekerti sesuai ajaran agama yang dianutnya. Kegiatan yang terkait dengan pembiasan karakter religius, yaitu salam, doa sebelum dan sesudah belajar.

Budaya mengintegrasikan karakter religius dalam kegitan ekstrakurikuler terkait dengan pembiasaan salam, Doa sebelum dan sesudah belajar, Sholat Dhuha, peringatan hari besar islam, Membaca Al-Ma'tsurot, memakai peci, Kegiatan tadarus, penelolaan infak, dan dahwah romadhan.

Budaya mengintegrasikan karakter religius dalam kegitan kokurikuler, terkait dengan pembiasaan Baca Tulis Al-qur'an, kultum ba'da dhuhur, Peringatan Hari Besar Islam, zakat dan qurban.

Berbagai ucapan terima kasih kami sampaikan kepada berbagai pihak yang telah mendukung kegiatan penelitian ini. Ucapan terima kasih kami sampaikan kepada Direktorat Riset dan Pengabdian Masyarakat Direktorat Jenderal penguatan Riset dan Pengembangan 
Kementerian Riset, Teknologi, dan Pendidikan Tinggi yang telah membantu dalam pendanaan biaya penelitian mono tahun melalui Hibah Penelitian Tesis Magister. Ucapan terima kasih kami sampaikan kepada Direktur Sekolah Pascasarjana dan Ketua Lembaga Penelitian UMS beserta stafnya, yang telah memberikan fasilitas dan dorongan sehingga kami bisa melakukan penelitian. ucapan terima kasih juga kami sampaikan kepada kepala Dinas Pendidikan Kota Surakarta, kepala dan guru SD Muhammadiyah 16 Karangasem Surakarta, yang telah membantu proses penelitian sehingga berjalan sesuai perencanaan.

\section{DAFTAR PUSTAKA}

Abdillah, R.A. 2015, Strategi Dan Implementasi Pelaksanaan Pendidikan Karakter Di Smp N 9 Yogyakarta. Jurnal Pendidikan Karakter Edisi April 2015, TH. V, No.1

Amaruddin, H., Atmaja, H.T., \& Khafid, M. 2020, Peran Keluarga dan Media Sosial dalam Pembentukan Karakter Santun Siswa di Sekolah Dasar. Jurnal Pendidikan Karakter, Tahun X, Nomor 1, April 2020, hlm. 33-46.

Bambang D., \& Eny. 2017. Implementasi Penguatan Pendidikan Karakter Di Sekolah. Bangun Rekaprima Vol.03/2/Oktober/2017

Daryanto, 2015, Pengelolaan Budaya dan Iklim Sekolah, Yogyakarta: Gaya Media.

Hamid, A. (2017). Pendidikan Karakter Berbasis Pesantren: Pelajar dan Santri dalam Era IT \& Cyber Culture. Surabaya: IMTIYAZ.

Handayani, N. \& Indartono, S. (2016). The Implementation of Multicultural Character Education. International Conference on Ethics of Business, Economics, and Social Science , 508518. Joel Stein (2013).

Hermino, A., 2016, "Asean Economic Community in The Perspective of Transformational Leadership In School”, International Journal of Education and Research, Vol. 4 (6), pp. 401-416. Diperoleh dari http://www.ijern.com/journal/2016/June-2016/35.pdf (diunduh tanggal 10 Juni 2017)

Johnson, E. B., 2010, Contextual Teaching and Learning, Menjadikan Kegiatan BelajarMengajar Mengasyikkan dan Bermakna, Bandung: Mizan Media Utama.

Jumroatun, L., et al. 2018, Implementasi Budaya Sekolah Islami dalam Rangka Pembinaan Karakter Siswa. JAMP: Jurnal Adminitrasi dan Manajemen Pendidikan Volume 1 Nomor 2 Juni 2018, Hal : 206-212 Tersedia Online di http://journal2.um.ac.id/index.php/jamp/ ISSN 2615-8574 (online) (diunduh tanggal 10 Juni 2019)

Kesuma, D., Triatna, C., dan Permana, J., 2017, Pendidikan Karakter Kajian Teori dan Praktik di Sekolah, Bandung: Remaja Rosdakarya.

Kosim, A. 2019, Internalisasi Pendidikan Karakter Berbasis School Culture, Jurnal Wahana Karay Ilmiah_Pascasarjana (S2) PAI Unsika Vol. 3 No. 1 Jan-Juni 2019, hal. 240-251.

Lisnawati, S., 2016, “The Habituation Of Behavior As Students' Character Reinforcement In Global Era", Journal of Education, Vol. 2 (3), pp. 413-428. Diperoleh dari http://journal.uinsgd.ac.id/index.php/ipi/article/view/852 (diunduh tanggal 10 Juni 2017)

Maryono, 2015, "The Implementation of Character Education Policy at Junior High Schools and Islamic Junior High Schools in Pacitan", International Journal of Education and Research, Vo. 3(5), pp. 267-274. Diperoleh dari http://www.ijern.com/journal/2015/May- 
2015/23.pdf (diunduh tanggal 2 Juni 2019).

Marzuki \& Haq, P.I. 2018, Penanaman Nilai-Nilai Karakter Religius dan Karakter Kebangsaan Di Madrasah Tsanawiyah Al falah Jatinangor Sumedang. Pendidikan Karakter, Tahun VIII, Nomor 1, April 2018 (diunduh tanggal 24 Juli 2020).

Miles, M.B, \& Huberman, A.M. 2018. Analisis Data Kualitatif. Terjemahan oleh Tjetjep Rohendi R. Jakarta: Penerbit Universitas Indonesia.

Moleong, L.J. 2017. Metodologi Penelitian Kualitatif. Bandung: Rosdakarya.

Murdiono, M. 2018. Strategi Internalisasi Nilai-nilai Moral Religius dalam Proses Pembelajaran di Perguruan Tinggi. Cakrawala Pendidikan, Th. XXIX, Edisi Khusus Dies Natalis UNY, hlm. 99-111.

Murtako, M., 2015, "Culture-Based Character Education in Modernity Era", Journal of TA'DIB,Vol.20(1),pp.149164.http://download.portalgaruda.org/article.php?article=38891 $\underline{9} \& \mathrm{val}=7615 \& \mathrm{title}=$ CULTURE-BASED\%20CHARACTER\%20 EDUCATION \%20\%20IN\%20MODERNITY\%20ERA (diunduh tanggal 10 Juni 2019).

Mushfi, M. \& Fadilah, N. 2019. Internalisasi Karakter Religius di Sekolah Menengah Pertama Nurul Jadid, Jurnal MUDARRISUNA Vol. 9 No. 1 Januari-Juni 2019, hlm. 1-22, diakses tanggal 25 Juli 2020.

Muslich, M. 2016. Pendidikan Karakter Menjawab Tantangan Krisis Multidimensional. Jakarta: PT. Bumi Aksara

Neprializa, 2015. Manajemen Budaya Sekolah. Manajer Pendidikan, Volume9, Nomor3,Juli 2015, hlm.419-420

Ningrum, W. S. 2016. Implementasi Pendidikan Karakter Melalui Budaya Sekolah di SD Negeri 2 Blunyahan. Fakultas Ilmu Pendidikan, Universitas Negeri Yogyakartaemail:wenny.sulistya2016@student.uny.ac.id

Nugroho, P. 2017, Internalisasi Nilai-Nilai Karakter dan Kepribadian Mahasiswa Pendidikan Agama Islam Melalui Pendekatan Humanis-Religius, Jurnal Pendidikan Islam, Vol. 12, No. 2, Agustus 2017, hlm. 355-379.

Oktarina, 2015. Implementasi Pendidikan Berbasis Budaya Lokal di Sekolah Dasar Negeri Krebet Tahun Pelajaran 2015/2016. Program Studi Pendidikan Guru Sekolah Dasar Fakultas Keguruan dan Ilmu Pendidikan Universitas PGRI Yogyakarta

Pattaro, C., 2016, "Character Education: Themes and Researches. An Academic Literature Review", Italian Journal of Sociology of Education, Vol. 8(1), pp. 6-30. Diperoleh dari http://ijse.padovauniversitypress.it/system/files/papers/2016_1_2.pdf (diunduh tanggal 11 Juli 2020).

Pradana, Y. 2016. Pengembangan Karakter Siswa Melalui Budaya Sekolah (Studi Deskriptif di SD Amaliah Ciawi Bogor). UCEJ, Vol. 1, No. 1, April 2016, Hal. 55-67. Untirta Civic Education Journal. ISSN : 2541-6693 (Diterima 29 Februari 2016; direvisi 10 Maret 2016; disetujui 20 Maret 2016) diunduh tanggal 4 Juli 2020.

Putry, R. 2018, Nilai Pendidikan Karakter Anak di Sekolah Perspektif Kemendiknas, Gender Equality: Internasional Journal of Child and Gender Studies, Vol. 4, No. 1, Maret 2018, hlm. 39-52.

Ramadhanti, M., Sumantri, M.S., \& Edwita. 2019, Pembentukan Karakter Dalam Pembelajaran BCTT (beyond center and circle time), Jurnal Educate, Vol. 4 No. 1 Januari 2019, hlm 917. 
Sahlan, A. (2010). Mewujudkan Budaya Religius di Sekolah. Malang: UIN Press Maliki.

Sarafuddin. 2019, Internalisasi Nilai Pendidikan Karakter Melalui Metode Pembelajaran Contextual Teaching And Learning Dan Pembiasaan Membaca Al-Qur'an Untuk Menangkal Pengaruh Kemajuan Teknologi Informasi Dan Komunikasi Di Tingkat Sekolah Dasar, Widya Wacana Vol. 14 Nomor 1, Februari 2019, hlm 9-19.

Setiyaningrum \& Agustini. 2015. Membangun Karakter Siswa Melalui Budaya Sekola Di Sekolah Dasar. Program Pascasarjana Universitas Negeri Yogyakarta. Jurnal Pendidikan Karakter, Tahun V, Nomor 2, Oktober 2015.

Sivo, S., Karl, S., Fox, J., Taub, G., and Robinson, E., 2017, "Structural Analysis of Character Education: A Cross-Cultural Investigation", School Psychology Forum: Research in Practice, Vol. 11(2), pp. 33-44. https://www.edcollege.ucf.edu/wpcontent/uploads/sites/8/2017/12/ResearchSivo.pdf (diunduh tanggal 4 Juni 2017)

Sugiyono, 2017, Metode Penelitian Kuantitatif, Kualitatif dan $R \& D$, Bandung: Alfabeta.

Supranoto, H. 2015, Implementasi Pendidikan Karakter Bangsa dalam Pembelajaran SMA. Jurnal: Promosi, Vol.3, No.1 hlm.36, https://fkip.ummetro.ac.id/journal/index.php/ekonomi/article/view/141/112, diakses pada tanggal 24 Juli 2020.

Sutama, 2019. Metode Penelitian Pendidikan, Kuantitatif, kualitatif, PTK, Mix Method, R\&D. Sukoharjo: CV. Jasmine.

Suwandayani, B.I. \& Isbadrianingtyas, N. 2017. Peran Budaya Sekolah Dalam Pembentukan Karakter Anak Sekolah Dasar. Program Studi Pendidikan Guru Sekolah Dasar. Prosiding SENASGABUD http://researchreport.umm.ac.id/index.php/SENASGABUD. (Seminar Nasional Lembaga Kebudayaan). Edisi 1 Tahun 2017 Halaman 34-41 E-ISSN 2599-8406

Tilaar, 2014. Pendidikan Kebudayaan dan Masyarakat Madani Indonesia. Bandung: Remaja Rosdakarya.

'Ulum, S. H. \& Koesdyantho, A.R. 2018, Internalisasi Nilai Pendidikan Karakter Melalui Pembiasaan Membaca Alquran, Jurnal Sinektik Volume 1 Nomor 2, Edisi Desember 2018, hal. 22-236.

Usman,M. \& Widyanto, A. 2019, Internalisasi Nilai-Nilai Toleransi dalam Pembelajaran Pendidikan Agama Islam di SMA Negeri 1 Lhokseumawe, DAYAH: Journal of Islamic Education Vol. 2, No.1, 2019, 36-52, diunduh tanggal 24 Juli 2020

Wagner, 2014. Leadership for an Improved School Culture. How to Assess and Improve the Culture of Your Culture. Kentucki: Kentucki School Leader (online). Diakses padatanggal2Juli 2020 dari http://www.schoolculture.net/kyschoolleaderfall04.pdf.

Wibowo, A. 2012, Pendidikan Karakter: Strategi Membangun Karakter Bangsa Berperadaban, Yogyakarta, Pustaka Pelajar.

Zulmy, A. N. 2019. Penguatan Budaya Sekolah Dalam Membentuk Karakter Siswa di MAN Kota Surabaya dan SMA Muhammadiyah 9 Surabaya. Tesis, Program Pascasarjana, Jurusan Pendidikan Islam, Prodi Magister Pendidikan Agama Islam, Universitas Islam Negeri Sunan Ampel Surabaya. Tidak dipublikasikan 